\begin{tabular}{|c|c|c|}
\hline & $\begin{array}{l}\text { ANNALES INSTITUTI SLAVICI } \\
\text { UNIVERSITATIS DEBRECENIENSIS }\end{array}$ & \\
\hline SLAVICA XLVIII & 2019 & DEBRECEN \\
\hline
\end{tabular}

Ангелика МОЛНАР

\title{
ПУТИ ИЗУЧЕНИЯ МЕТАФОРЫ В СОВРЕМЕННОМ ЛИТЕРАТУРОВЕДЕНИИ*
}

\author{
The Theory of Metaphors in Contemporary Literary Studies
}

\begin{abstract}
This article is designed as a brief overview of the methods of how metaphor is defined in contemporary scholarship. In the discussion of the similarities and differences of the basic Russian and Western poetic, philosophical and logical approaches to metaphors are compared to each other. Besides, Hungarian comprehensive syntheses and reconsiderations of metaphors are also touched upon. Finally, suggestions are made as to which aspects of literary studies and linguistics can be used in the analysis of the system of tropes in literature.
\end{abstract}

Keywords: theory of metaphor, classifications, poetics, linguistics methods

Разнообразие определений метафор и подходов к ней, рассматривающих её не просто как сгущенное, сокращенное сравнение, невероятно богато. В русской и западно-европейской филологии для проведения тропологических исследований использовались в основном те же теории метафоры (М. Блэк, А. Ричардс, П. Рикёр и др.), философии языка и поэтики (А. Потебня, О. Фрейденберг, М. Бахтин и др.), которые рассматриваются в настоящем обзоре. Помимо основных разделений на основе переноса (см. значение греч. metaphora) по сходству (аналогия), замещению (переносное значение вместо буквального значения) или интеракции (оппозиция / взаимодействие образа и значения), предложены типологии и классификации на базе функции, семантики и структуры тропа (Ю. Левин, А. Баранов и др.); метафоры анализированы со стороны объекта и языка, форме и семантике и т.п.; учтена их онтология и употребление (Н. Арутюнова, Дж. Лакофф и М. Джонсон и др.); а также описаны индивидуально-авторские метафоры в идиостиле самых разных поэтов и писателей, в частности, Б. Пастернака (Н. Фатеева).

Необъятость материала не позволяет осуществить широкий обзор теории метафоры, несмотря на то, что имеются многочисленные систематизации подходов, начиная с их разграничения на поэтические и риторические [HORVÁTH 2003] вплоть до их изучения с точки зрения двух- или трехкомпонентности [ШЕЛЕСТЮК 2001]. В узких рамках настоящей статьи мы ограничимся лишь теми определениями этого тропа, которые оказали сильное влияние на форми-

Работа выполнена при поддержке гранта РФФИ 19-512-23004 «Метафорическая картина мира современной русской и венгерской прозы конца XX - начала XXI в. (сопоставительный анализ)». 
рование современного поэтического подхода к литературному тексту и, следовательно, имеют важное значение и для нас при анализе индивидуальных произведений. Кроме того, в нашем исследовании по «Метафорической картине мира в современной русской и венгерской прозе», предполагающем выявление как общих компаративных тропов, так и национальной специфики современных прозаических текстов, мы руководствуемся не только литературоведческими положениями, а других научных дисциплин, рассматривающих феномен метафоры, в первую очередь лингвистики, с позиции, направленной на выявление универсальных образных соответствий, выражающихся в метафорических конструкциях. Динамичность и инновативность таких поэтических средств в современных текстах усиливаются и в результате конфликта, возникающего из-за их столкновения с прозаическими конструкциями. В нижеследующем кратком обзоре мы обратимся к основным русским и западным теориям и венгерской рецепции этих теорий, чтобы показать их применимость в изучении языка и поэтики литературы. Сопоставим более традиционные и современные подходы к метафоре, которые представляют собой поэтические, риторические, философские, литературоведческие и лингвистические аспекты.

Уже Аристотель различает риторическую метафору, механически бытующую в естественном языке, и поэтическую метафору, которая поражает нас неожиданностю, новизной аналогий, установленных ею [ARISZTOTELÉSZ 1997]. Первая снова приобретает особую значимость в когнитивной лингвистике, а последняя встречается в первую очередь в литературных текстах. С целью рассмотрения возможности соотношения этих полюсов, прежде всего следует кратко рассмотреть, как определяется язык и мысль в связи с метафорой в русско-советской поэтике, а затем и в языковедении.

Многие теоретики языка воспринимают его метафорически - человеческим организмом или машиной (см. порождающая грамматика). Язык однако выражает не продукт, а способ мышления человека [ВыГОтский 1999: 285]: «мы мыслим словами» [KOSZTOLÁNYI 1971: 46]. Доказательством тому служит, например, этимологическая связь слов «душа», «дух» и «дыхание», или же творческий опыт поэтов и писателей. Выдающийся венгерский модернист Дежё Костолани утверждает текстопорождающую роль внешней, звуковой оболочки слов, а также, важность контекстуального смысла, образующегося в результате переноса слова в необычное окружение, и меняющего мысль автора, «содержание» произведения [KOSZTOLÁNYI 1971: 216].

В этой связи нельзя обойти вниманием и тезисы крупного языковеда XIX века Александра Афанасьевича Потебни, раскрывающие связь языка и мышления. Они имеют первостепенную важность для наших исследований. Актом, определяющим существование человека, является называние элементов мироздания, поэтому язык и является проекцией мировосприятия. Положение о трехкомпонентности знака Вильгельма фон Гумбольдта [ГумБОльдт 2000: 107], которое развил и расширил на произведения Потебня, сегодня особенно актуально, так как функции компонентов, мотивированность их соотношения, подвергаются сомнению лингвистами и со времен Фердинанда де Соссюра. 
Если следовать мысли Потебни, метафора не может быть языковым дефектом, ибо каждое новое слово является результатом особого сравнения «вновь познаваемого $X$ и прежде познанного $A$ посредством представления $a \gg$, как значения знака, внутренней формы, сохраняющей исторически закрепленные значения в звуковой форме [ПоТЕБНя 2003: 147]. Таким образом, согласно ученому, поэтичность языка реализуется посредством сопоставительного признака (tertium comparationis). Следовательно, метафора - не элемент риторического украшения, даже если в слове она может забываться, стереться от частого употребления и стать прозаической, научной. Это значит, что если представление, активно участвующее в конструировании текста, живое и не забытое, то прозаический язык также можно назвать поэтическим, а в поэтическом языке (литературы) метафора «оживает», становится действенной.

Теория тропов, разработанная Потебней, является одной из самых полных и актуальных и в наши дни. Подобно тому принципу, как ученый определяет слово, так же предлагает различить три группы словообразования или изменения значений - по системе разных внутренних отношений образа и значения. В синекдохе прежнее значение заключено во вновь обозначаемом и наоборот. В метонимии вновь обозначаемое только частично содержит значение раньше обозначенного. А в основном тропе, метафоре признаки сочетаемых понятий исключают друг друга, но воссоздают общий, третий элемент, новый образ (см. «любви фиал») [ПОТЕБНЯ 2003: 179]. Из этого следует, что метафора определяется посредством сдвига в значении. Это не «художественная типичность», т. е. иносказательность в широком смысле [ПотЕБНЯ 2003: 155], а, скорее, сближение.

По этой теории, особенность метафоры заключается в подобии, которое создается вопреки различиям, выявленным во вновь и раньше отмеченных признаках. Это положение можно отнести к теориям сравнения, с той оговоркой, что в нем присутствуют элементы замещения. Приведем пример. Механизм метафоризации Потебня представляет как новое соотношение: «старость» относится к «жизни» как «вечер» ко «дню», и, в результате, образуется метафора «старость дня» $(1: 2-3: 4=1: 4)$. Подобное же сближение наблюдается в выражении «капля жалости» (капля: вода - слеза: жалость 1:2-3:4=1:4) [ПоТЕБНЯ 2003: 223]. Признаки обозначают вещь и наоборот, в таком порядке, как еще никогда раньше - т. е. творчески. При этом представитель лингвистической поэтики обращается к иносказательности в тесном смысле.

Он также изучает в этом отношении и мифы. Делая небольшой экскурс, отметим, что ученый полемизирует с тем взглядом, будто источником мифа являлись неправильно понятые метафоры, так как если миф, в котором «образ целиком (не разлагаясь) переносится в значение» [ПОТЕБНя 2003: 329], является актом познания, то в поэзии, вырастаемой из мифа, вновь познаваемое от прежде познанного предельно резко отличается. Добавим, что Эрнст Кассирер же сводит метафору к мифотворчеству на том основании, что миф и язык сродны и отличаются от логического мышления [КАССИРЕР 1990: 33]. В этом плане интересно, что немецкий философ также, как и (мало)русский лингвист, считает метафору основой языка и связывает её с порождением нового звукового знака. 
Как утверждает Потебня, тропы («образы») и фигуры слов используются независимо от жанра произведения и несут оценочный избыток. Согласно ученому, слово само по себе является произведением искусства, «поэзией», и, в свою очередь - «актом мысли» [ПотЕБНЯ 2003: 338], «мышлением при помощи образа» [ПоТЕБНя 2003: 179]. Здесь делается главное ударение не на когнитивное познание (прежде познанного и нового), а на обозначение и изменение значения, т. е. на семиотизацию и семантизацию, в результате которых рождается новый взгляд на мир. Итак, слово и мысль следует считать общими явлениями, становящимися и развивающимися динамично.

Потебня классифицирует метафоры, в частности, с точки зрения их оформления. Различая простые и сложные метафоры по языковым и грамматическим способам их выражения, он утверждает, что они часто встречаются в форме олицетворений [ПотЕБНЯ 2003: 226]. Развернутыми метафорами могут стать целые произведения, как Потебня доказывает это на примере аллегорий, басен и притч. То, что утверждалось относительно слова (оно трехсоставное и его литературносемантическая память - «сообщение опыта» [ПОТЕБНя 2003: 57]), переносится и на художественное произведение, которое и есть «средство создания мысли» [ПОТЕБНЯ 2003: 32]. Итак, помимо идеи языкового представления, как обычной словесной метафоры, ученый выявляет особенность поэтической метафоры, создаваемой литераторами. Следовательно, лишь в плане «художественной типичности» можно толковать литературные тексты как примеры познания.

Поэтическую передачу опыта и мышление Потебня понимает не в когнитивных категориях, а с точки зрения творчества. Научное познание, несмотря на понятийное объективирование предмета, несовершенно, ибо скрытую и настоящую сущность предметов и еще неопознанные и необозначенные явления позволяет ощутить, осветить, представить исключительно поэзия. А поэзия же есть большая, недоступная метафора, которую требуется разгадать, и именно так она оказывает влияние на человека, индуцируя его мышление и творческую способность. Необычная метафора сложна тем, что требует много усилий для ее понимания. Ученый обращает внимание на то, что как образ произведения в качестве собирателя различных толкований, так и реципиент произведения придает особое содержание ему и делает это с положительным напряжением своего креативного потенциала.

Теория Потебни приобрела такую значимость для развития поэтики, что концепции остальных крупных исследователей мы представляем сквозь ее призму. Как нам кажется, благодаря положению изначальной метафоричности языка и можно сегодня лингвистам говорить о существовании метафорической картины мира. Для воспроизведения такой картины и предлагается нами изучить генезис и семантику слов, ибо язык содержит воспоминания о своей истории и порождении смысла.

Отметим, что метафорой считает поэзию, а сознание - творчеством и Хосе Ортега-и-Гассет [ОРТЕГА-И-ГАССЕТ 1990: 80]. Согласно испанскому писателюмыслителю, художественное творчество является формой ее настоящего бытия, а «наука лишь прибегает к метафоре» [ОРТЕГА-И-ГАССЕТ 1990: 68], чтобы 
сделать мысль более доступной. Такое наблюдение встречается и у Потебни, утверждающего, что научный язык становится вместилищем изжитых метафор. Ортега-и-Гассет дополняет разграничение языков тем, что если сопоставить эти две сферы в формальном плане, то можно увидеть, что наука представляет тождество абстрактных компонентов, а поэзия - двух конкретных веЩеЙ [ОРТЕГА-И-ГАССЕТ 1990: 73].

Вернемся к русско-советским теориям метафоры. Борис Викторович Томашевский в своем поэтологическом труде, написанном в качестве учебника (1925), но впоследствии ставшем базовым, рассматривает разные виды изменения значения слова [ТомАШЕВСКИй 2001]. Продолжая древнюю традицию, автор «Теории литературы. Поэтика» утверждает наличие эмоциональной окраски тропов, однако, отталкиваясь от положения Аристотеля о двусоставной форме метафоры, он подчеркивает значение контекста, (правда, пока еще узкого), ибо смысл слова рождается в предложении. Это последнее, по мнению формалиста, никакого отношения к образности не имеет, ибо вызывает не чувственные представления или субъективные ассоциации, а семантическое явление. Отметим, что именно в этом отношении следует отличить лингвистическую поэтику Потебни от взглядов его учеников, создавших т. н. «психологическую школу», на которую формалист и ссылается. Лингвист же подразумевает под внутренней формой слова «ближайшее этимологическое значение», содержащее все признаки мысли и создающее «представление» предмета, которое, в свою очередь, он соотносит с метафорой, как языковой конструкцией.

Томашевский также выявляет признаки вещей, обозначаемые словами, для установления аналогий. Механизм созидания такого нового соотношения формалист рассматривает, в том числе, и на примере развернутой метафоры, аллегории из В. Бенедиктова: «Могила любви», в которой извержение вулкана обозначает любовь. Он различает следующие типы метафор: глагольные и существительные, как «антропоморфические», т. е. когда явления природы сближаются с человеческими поступками, и наоборот, когда абстрактные явления заменяются конкретными. Отметим в этой связи, что приемом реализации метафоры, т. е. соединением слов в их прямом и переносном значении, широко пользовались поэты-футуристы (к примеру, «Вот так я сделался собакой» В. Маяковского). Томашевский ясно проводит черту между метафорой и другими видами тропов даже когда нелегко распознать границы, в частности, в случае метафорического эпитета (см. элемент сопоставления определяет слово) или оксюморона (эпитет противоположен определяемому). Отметим, что последнее особенно часто путалось с метафорой. Согласно основному аспекту подхода (изменение значения), действенным типом катахрезы ученый называет образование вторичного значения слова для нового явления или перенос значения старых слов. Сравнение же определяется им традиционно, т. е. здесь слова употребляются в их прямом значении, и обычно присутствует сопоставительное слово [ТОмАШЕВСКиЙ 2001: 60]. Формалист разграничивает языковые, т. е. «стершие» при повторении, и стилистические метафоры, которые оказывают воздействие своей новизной. Однако последние он понимает 
лишь риторически, а не учитывая их смыслопорождающую роль в целостном литературном тексте.

Можно сравнить это различение, сделанное Томашевским, с определениями, предложенными современными исследователями: традиционные («мертвые») и подлинные метафоры влияют на рецепиентов с разной силой. Так, встречаются эксперименты сделать метафоры сильнее, т. е. увеличить степень их новизны и неожиданности. Как нам кажется, метафоры производят наиболее сильный эффект именно в литературе, по этой причине наше внимание привлекают теории, которые стараются раскрыть это инновативное действие метафор.

Свежий взгляд вносит в теорию Ольга Фрейденберг, согласно которой, в то время как античная метафора представляла семантическое тождество двух ее членов, современная создается «По перенесению признака» [ФРЕЙДЕНБЕРГ 1978: 188]. Ученая убедительно доказывает реализацию тематических или сюжетных мотивов в метафорах, развернутых в словесные действия, так как, по ее мнению, наблюдается взаимосвязь между возникновением наррации и метафоризации [ФРЕЙДЕНБЕРГ 1936: 248]. Такой подход позволяет расширить наши знания о действии метафор в прозе, ибо различая тему («образ»), мотивы, которые эту тему разрабатывают, и словесные метафоры, которые эти мотивы реализуют в тексте, можно утверждать, что сюжет прозаического произведения тематизирует семантику слова, обозначающего действие, т. е. манифестирует смыслопорождение.

Типологические отголоски же положений Потебни можно обнаружить у Айвора Ричардса, который также утверждает метафорическую природу языка. Это у него появляется снова функция признака сопоставления (см. «грунд» / основание), помимо содержания (у Ричардса: средство, у Потебни: значение) и оболочки (см. тенор - образ), которые могут быть поняты только из контекста [РичАРдс 1990: 48]. Вслед за Ричардсом, Макс Блэк также принимает синтагматическую форму метафоры, однако - в двусоставности метафорического процесса. Этот процесс он определяет как «интеракцию», т. е. взаимодействие «фокуса» (метафорического слова) и «рамы» (других слов), столкновение двух мыслей в одном выражении. Итак, здесь делается ударение на соотношение между значениями, создающее сходство [БлэК 1990: 156]. Новая теория сдвинула с места определение метафоры, как явления, имеющего стабильное, переносное значение, в сторону динамического смыслопорождения.

Отметим и позицию Филиппа Уилрайта, соглашающегося с тем, что метафора примиряет противоположные и несовместимые качества [УИлРАЙт 1990: 91], но помимо этого литературовед еще отличает механизмы перенесения, установления новых сходств (эпифора), от простого соположения (диафора), порождающего новое значения [УИлРАЙт 1990: 83]. Он детально описывает превращение метафор в символы подобно мифопоэтическим концепциям (см. выше) [УИЛРАЙТ 1990: 108].

Переосмысляя теоретическую традицию, соединяющую повествование с метафорой, Поль Рикёр сходство в основе метафоры манифестирует как способ «предикации признака субъекту», при которой возникает семантическая 
несогласованность в высказывании [РиКЁР 1990а: 438]. В «живой метафоре»как определяет ее ученый - раньше несовместимые элементы вступают в новые соотношения [РИКЁР 1990б: 452]. Это и вызывает метафорическую напряженность, противоречие в излагаемом тексте, и, в результате, явная бессмысленность прямого толкования по привычным представлениям требует поиск новых смыслов. Изучение рецептивного процесса метафоры и подтверждает подобное заключение. Как нам кажется, именно эта инновация и сможет описать мир по-новому посредством творчества, а не объяснять и познать его. Продолжая развивать мысль Рикёра в свете идей Потебни, метафорический процесс можно понимать как словотворчество, основанное на обновлении знаков, новом означивании, как особой формой поэтизации и условием смыслопорождения. Таким образом, ученый совмещает в своем подходе поэтологическую, герменевтическую и нарратологическую позиции, переводя толкование метафоры в семантический план.

Западно-европейские теоретики второй половины XX века определяют метафору с других точек зрения, включая и структуралистскую. К примеру, Цветан Тодоров считает условием литературности и поэтического текста риторические средства, которые нивелируют референциальность [TODOROV 1977: 30]. Жерар Женетт обнаруживает в метафоре немотивированное отождествление без сравниваемого, и не позволяет свести языковую фигуративность исключительно к метафоре, утверждая, что метафора и метонимия поддерживают друг друга [GENETTE 1977: 65]. Добавим, что Поль де Ман же усматривает между ними амбивалентное, саморазрушающее движение [DE MAN 1999: 89]. Итак, во-первых, риторический и логический аспекты изучения все сильнее станут охватывать научную мысль о метафоре, отодвигая семантику на второй план, а во-вторых, функция других тропов и поэтических средств также выдвигается в изучении художественной прозы. Укажем в этой связи на соотнесение Романом Якобсоном принципа метафоры со стихотворными текстами, а метонимии с художественной прозой [ЯкОБСОН 1990: 126]. Отметим, что впоследствии все сильнее провозглашается ученым требование изучать функционирование метафоры в прозе не просто по механизму выбора и комбинации, а как поэтическую интеракцию, не случайно же он присвоил литературе доминанту поэтической функции.

На рубеже XIX-XX веков аналитическая философия и лингвистика, логика и прагматика начинают снова вступать в свои права и вытеснять поэтику, несмотря на следующие поиски, представляемые помимо других также в сборнике «Теория метафоры» [АРУТЮНОВА-ЖУРИНСКАЯ 1990]. Польский лингвист Анна Вежбицкая посредством формальных категорий демонстрирует структурную разницу между сравнением («что могло бы быть») и метафорой, в которой сокращается противопоставление («это не») [ВЕЖБИЦКАЯ 1990: 144]. Тереза Добжиньская же обращает внимание на поэтическую роль контекста и условие связности литературного текста, ибо жанровая принадлежность 
текста также определяет возможность метафорического толкования [ДоБжИНЬСКАЯ 1990б: 476]. Добавим, что анализом дискурса также подтверждается, что метафора способствует текстовой сплоченности.

В своей научной полемике с Нельсоном Гудменом, утверждающим образную функцию метафоры [ГУДМЕН 1990: 195], выявляя законность логических подходов к этому тропу, Дональд Дэвидсон вводит в свою модель непознавательной метафоры как логический критерий «истинности или ложности», так и аспект интерпретатора, который участвует в конструировании метафоры [Дэвидсон 1990: 173]. Отрицая однако наличие в метафоре иносказательного смысла, а также возможность научного описания того, что метафора представляет, философ переводит акцент с функции на её речевое употребление [ДэВидСОН 1990: 187]. Литературовед Монро Бирдсли же, словно полемизируя с этой концепцией, указывает на то, что при буквальном использовании слов не может возникнуть конфликт значений, который скрывается в метафоре [БИРДСли 1990: 207]. А философ Эндрю Ортони также, как и Дэвидсон, предлагает определить метафору в прагматическом контексте. И по типу уилрайтовского разграничения метафор, он различает метафоры, в которых выдвигается предикат, и метафоры, посредством которых вводятся предикаты и так узнается нечто новое [ОРТОНИ 1990: 234].

Психологический процесс восприятия, понимания и толкования метафоры анализируется Джорджем Миллером. Соотношение по сходству вновь познаваемого с тем, что уже известно, для Потебни творческий процесс, однако Миллер приходит к заключению, что именно предполагаемое познание, приобретение новых знаний позволяет сделать метафору когнитивным инструментом, ибо, как ему кажется, «в новых метафорах меняются не значения слов, а наши убеждения, касающиеся вещей» [МИллЕР 1990: 277]. На наш взгляд, это характерно для обычных метафор. Таким же образом, в отличие от утверждения например, Томашевского, по мнению Джона Серля, в метафоре не происходит изменение значения, только семантический сдвиг [СЕРЛь 1990: 315]. Ученый полемизирует и с традиционными определениями метафоры (не сходство и не взаимодействие), однако утверждение им необходимости условий истинности свидетельствует о подобной, как у Дэвидсона, позиции. Обращение к мыслительным процессам отражается в его положении о том, что метафора способствует выражению раньше невыразимых мыслей [СЕРЛЬ 1990: 340].

Таким образом наблюдается переход от философско-логического описания метафоры к когнитивному лингвистическому. Как утверждает Сэмюэль Левин по Соссюру, метафорические высказывания могут основываться не на семантических отклонениях, но нарушают нормы употребления языка [ЛЕВин 1990: 355]. В отличие от него, Дерек Бикертон считает, что лишь лингвистический подход, исключающий логический аспект, может по-новому и правильно систематизировать метафору [БИКЕРТОН 1990: 284]. Он требует «расширение системы присвоения атрибутов» для комбинации категорий «Абстрактное и Одушевленное, Животное и Человек, Человек и Артефакт» [БИКЕРТОН 1990: 304]. 
Другой лингвист Эрл МакКормак также объясняет метафору, как когнитивный процесс, ибо при создании нового смысла посредством несопоставимых концептов на самом деле познается мир [МАККОРМАК 1990: 359]. Он называет базисной метафору, на которой строится объяснение. В нашем подходе базисной именуется коренная метафора литературного текста (или же всего творчества писателя), которая связывает его в целое и управляет его смыслопорождением. Лингвист же расширяет стандартную категоризацию «истинности / ложности» до четырехзначной [МАККОРМАК 1990: 363], но познавательный аспект, строящий компьютерную метафору (см. разум - мозг - язык), раскрывает не смысл поэтического текста.

Когнитивная лингвистика в труде Джорджа Лакоффа и Марка Джонсона «Метафоры, которыми мы живем» [ЛАКОФФ, ДжонСОН 2004], связывает язык с познанием и вводит в теорию метафоры концептуальный аспект. Языковеды доказывают метафоричность всей понятийной системы, опирающейся на человеческом опыте, выявляя действие метафоры не только в языке, но и в мышлении [ЛАКОФФ-ДжОНСОН 1990: 387]. Отталкиваясь от поэтического подхода, ученые подчеркивают необходимость метафоры для понимания и человеческого общения. По их мнению, «стершиеся» выражения (обыкновенные, повседневные) вовсе не мертвы (ср. определение метафоры у Томашевского или Рикёра), а напротив, руководят мышлением любого человека, следовательно они еще «выразительны» и «действенны». Значит, они обращаются не к словам, а понятиям, которые в разных культурах осмысляются в разных категориях, следовательно, позволяют описать языковые картины мира разных народов [ЛАКОФФ-ДЖОНСОН 1990: 392].

Вспомним, как поэтологи объясняли соотношение абстрактной понятийной сферы и конкретных категорий. Эту связь лингвисты переводят на повседневную коммуникацию, относя разные понятия к сфере «цели» и сфере «источника», так как в ней проще раскрыть, как посредством более абстрактного концепта можно понять и осмыслить другой, конкретный. Многочисленные выстраиваемые соответствия между этими сферами называются проекциями, метафорическим языком выражений (см. «любовь» - «поездка»), а само отождествление - концептуальной метафорой. В этой связи различаются ориентационные (см. пространство), онтологические (количество) и структурные (корреляция) метафоры [ЛАКОФФ-ДжОНСОН 1990: 396-408].

В распространении этого подхода популяризаторская книга Золтана Ковечеша о метафоре также играет важную роль [KOVECSES 2002]. Здесь употребляются и термины Ричардса, правда, в несколько ином контексте. Фокусом значения метафоры является культурное наследие, из которого выбираются «присваемые свойства». Следовательно, рамкой должна быть область действия, целевая сфера метафоры. Функция метафоры заключается не в сообщении, а в способствовании мышлению. Исследователь перечисляет наиболее широкий и наглядный круг целевых сфер и источников повседневной речи, который типологизируется по содержанию (см. напр.: человеческое тело, животные, растения, строения, в связи с чувствами, мыслями, обществом). Автор 
различает виды метафор на основе их когнитивной функции, утверждая, что их универсальность исходит от общности человеческого мышления, и именно она позволяет сопоставлять разные человеческие продукции. Ковечеш в этом же русле предлагает способы использования данной теории в прикладной лингвистике, прагматике и вообще, комплексной концептуальной системе. При когнитивном подходе литературная метафора является лишь творческим расширением концептуальной. Ковечеш называет неконвенциональные, выразительные метафоры (см. напр. развернутую реализацию сочетания «любви и путешествия» в поэзии венгерского поэта Эндре Ади) «выпадающими из текста», сложными для понимания, поэтому в конечном счете им уделяется в книге гораздо меньше внимания [KÖVECSES 2005]. В повседневной речи же можно раскрыть, что выражение «мы находимся на перепутье» не означает то, что пассажиры, стоя на перепутье пытаются решить, куда идти дальше, а наоборот, то, что любовники должны принять одно, важнейшее решение в их отношениях.

Отметим, что имеется и опыт развития когнитивного изучения метафоры или же корректирования этих идей. К примеру, М. А. К. Халлидэй обращается к социальной лингвистике, и рассматривает идеальные, межличностные и текстовые типы использования языковых структур [HALLIDAY 1978]. Дж. Стин также проводит различие между концептуальным, лингвистическим и коммуникативным типами анализа [STEEN 1999]; Р. Гиббс представляет расширенную когнитивную обработку выражений [GIBBS 1994]; а М. Кортацци и Л. Джин исследуют прагматический аспект, например как учителя используют метафору [CORTAZZI-JIN 1999].

Укажем кратко и на российские поиски систематизации. В функциональных классификациях основанием является цель использования метафоры, в частности, декоративная, оценочная или эвфемистическая функция. В. Н. Телия различает идентифицирующую и образную (эстетическую, описательную) функции метафоры [ТЕлия 1988], а Н. Д. Арутюнова выделяет номинативную, образную, когнитивную и генерализующую метафору [АРУТЮНОВА 1999: 366]. Последняя раскрывает, чем отличаются тропы от символа, метаморфозы и т.п., убедительно доказывая, что функция метафоры не только в манифестации устойчивой сущности предмета, но прежде всего в языковом сдвиге в значении [АРУТЮНОВА 1990: 32]. В. П. Москвин разрабатывает не только структурную и функциональную, но также и семантическую типологизацию метафор [Москвин 1997: 64]

Добавим, что составлены словари образных средств. Продолжается лексикографический проект «Материалы к словарю метафор и сравнений», в котором Н. А. Кожевникова [см. также КожЕвниковА 2009] и 3. Ю. Петрова более расширенно группируют метафоры и сравнения по принадлежности предметов и образов сравнения к разным семантическим полям («Птицы»; «Звери, насекомые, рыбы, змеи»; «Растения»; «Камни, металлы»; «Ткани, изделия из тканей»). Базируясь на разные собственные исследования и работы Г. С. Баранова [БАРАНОВ 1992], и т. д. в области метафоры, по которым выделяется семантическая категория классификации (см. напр. по содержанию, предмету 
средства антропоморфные, зооморфные, вегетативные у С. М. Мезенина [МЕЗЕНИН 1984]), авторы словарей выявляют различные семантические отношения между словами в литературном тексте, диахронический принцип в плане написания или первой публикации соответствующего произведения, а также формально-синтаксические конструкции с учетом опорных слов. Зоя Петрова перечисляет также метафоры, в которых отношение сходства выражено эксплицитно и имплицитно [ПЕТРОВА 1989]. Сравнения также разделяются ею на разные типы и подтипы: без основания сравнения и с основанием сравнения. Кроме того добавлены другие конструкции, в том числе параллелизмы, которые также подвергаются анализу для раскрытия их смысловой мотивировки. Петрова приводит и структурный принцип классификации, созданный Ю. Левиным и основанный на формальном признаке (часть речи или предложения), которое создает метафоры-загадки, метафоры-сравнения, а также конструкции метафорического переназывания [ЛЕвин 1965: 293].

По следам Лакоффа и Джонсона систематизируются метафорические сочетания, в частности, и Л. Н. Рыньковым, который рассматривает их в структурном и семантическом плане [Рыньков 1975]. В. Г. Гак типологизирует процессы метафоризации [ГАК 1973]; Г. Н. Скляревская же - метафорические переносы (см. предмет, абстракция, животное, человек и т.П.) [СКЛЯРЕВСКАЯ 1993: 95]. Согласно первому, встречается полный метафорический перенос или двусторонняя метафора, односторонняя семасиологическая метафора, односторонняя ономасиологическая метафора, частичный метафорический перенос.

Сравним концептуальный подход с тем, что представлял Потебня. У него функция коренной поэтичности языка заключается в обьяснении нового явления посредством творческого создания нового слова о нем. И с точки зрения разницы соединения раньше известного с новым обозначаемым определяются и другие тропы, ибо каждое новое слово - метафора и она является основой всех тропов. Для круга когнитивных лингвистов основная функция метафоры - в понимании концептов. Этот подход направлен на раскрытие человеческого познания. Понимание же слова как метафоры, раскрытие взаимодействия элементов языка облегчает обращение к поэтическому тексту, и, выявляя творческий характер языка, как средства создания мысли [ПоТЕБНя 2003: 152], ведет не к познанию мира, а личностному пониманию.

Законность поэтического подхода к метафоре акцентируется и венгерскими исследователями. Корнелия Хорват в своей обзорной статье сталкивает риторические и языковые трактовки (см. включая труды таких известных теоретиков, как Ю. М. Лотман, Фридрих Ницше, Умберто Эко, Вальтер Беньямин или Жак Деррида), представляя аристотелевскую линию в сравнении с линией, исходящей от Потебни и относящей порождение тропов к универсальной поэтичности языка [HORVÁTH 2003]. Плодотворным являются размывания резких границ между линиями в силу включения в них семиотической роли тропов.

Кристиан Беньёвски же исследует возможные научные пути к сочетанию нарратологии и поэтики прозы, раскрытию нарративных метафор [BENYOVSZKY 2006]. Перенос значения по аналогии наблюдается им как в повествовательном 
плане, так и в сюжетосложении. Добавим, что эту идею развернула и Фрейденберг. Венгерский литературовед же на основании теории Якобсона считает, что метафоричность имеется и на разных уровнях метонимически организованного текста (план слова, предложения и композиции - см. композиционные метафоры), несмотря на то, что тропы в первую очередь используются в речи рассказчика или героя. Этот тип метафор автор статьи называет «локальными», т. е. стилистическими метафорами, функция которых в произведении эффекта, придачи наглядности. Приводя концепции современных венгерских и славянских нарратологов (см. Michał Głowiński, Vlastimil Zuska, Bogdan Pięczka), исследователь акцентирует этот принцип созидания метафор как в построении нарративных составляющих текста (время, пространство, роль читателя и т.п.), так и в тематической и формальной эквивалентности, разработанной Вольфом Шмидом.

Габор Безецки рассматривает развитие концепций о метафоре, начиная с конфликта «Новой критики» и аналитической философии (см. выше), который он считает коренной проблемой и современных теорий. Венгерский исследователь приходит к убеждению о необходимости привлечения языкового аспекта, однако утверждает, что чисто лингвистический подход, основанный на установлении правил, положений о «нормальном языке» и его девиациях, не может раскрыть своеобразие метафоры [BEZECZKY 1990: 383]. Литературоведческое изучение метафоры как чисто языкового феномена, который создает новое значение, позволяет правильнее описать его и приблизиться к литературным отклонениям от нормы. В то же время, языковое значение литературных предложений следует отличить от интерпретационного смысла литературных произведений [BEZECZKY 2002: 27]. Безецки по этой причине подчеркивает значение работ Пола Рикёра о метафоре, в которых ведутся поиски согласования разных дисциплин. Интерпретируя же теорию Рикёра, венгерский исследователь утверждает возможность расширения метафоризации на весь текст, усматривая взаимосвязь между местной и глобальной метафоричностью [BEZECZKY 2002: 209]. Он также связывает метафору и наррацию, ссылаясь на положения Герберта Рида, Вальтера Аллена и других западных теоретиков. Безецки ищет разрешение конфликта о метафоричности двух крайностей лингвистических и пост/структуралистских теорий. Под таким углом зрения он подвергает критике и утверждения Хомского о машинности языка и Де Мана о машинности универсума [BEZECZKY 2002: 193]. Языковой аспект, по мнению Безецкого, находит свою настоящую реализацию в социальном использовании языка в том смысле, как это понимает в своей философии языка М. М. Бахтин (ср. диалог многих языков). Бахтин же в своей теории романа противопоставляет две разные контексты также, как и интеракционистская концепция [BEZECZKY 2002: 212]. Таким образом венгерский исследователь соотносит раньше несопоставленные подходы социолингвистики и поэтики, предполагая, что на многоязычном взаимодействии может основываться и теория метафоры [BEZECZKY 2002: 218]. 
Теоретик дискурсивной поэтики, Арпад Ковач осваивает наследство крупных предшественников-поэтологов и филологов, в первую очередь Потебни, Бахтина, Бенвениста, Рикёра, Фрая. В понимании ученого поэтическое смыслопорождение требует семантической реактивизации всех трех компонентов языкового знака (звуковой оболочки, внешней и внутренней формы). Они вступают во взаимодействие со своими эквивалентами в тексте, и образуют новые, неожиданные сочетания. Ученый выдвигает еще один организующий принцип текста - реэтимологизацию слова. Новая, уникальная семантика на уровне высказывания тематизируется и становится органом порождения смысла в тексте. На уровне сюжета образуется история, а в наррации - повествование, тогда как на уровне языковой презентации высказывания (дискурса) порождается инновация конвенциональной семантики слов. Таким образом свершается активизация метафорической полисемии слова, обозначается новый общий признак между вещами данной тематики. Под метафорой можно понимать текстовое слово, ставшее компонентом метафорического словосочетания, сближающего отдаленные понятия и создающего целостность текста поэтического произведения. Будапештская школа поэтики обсуждает поэтическую функцию метафоры на уровне дискурса, т.е. не в рамках имени или предложения. А значит, не просто как аналогию, сопоставление, замещение или взаимодействие, а в рамках текстопорождения, свершающегося в неповторимом акте высказывания. Это значит, что инновации в звучании, слове и высказывании интегрируются в дискурс как семантическое целое личного высказывания. [КОВАЧ 2015].

Ковач вводит термин «экзистенциальной метафоры» [KoVÁCS 2013], а также переосмысляет уникальное металингвистическое (основанное Бахтиным) образование «интонационной метафоры», которая предваряет семантическую метафору и служит осмыслению единичного сюжетного поступка, тематизированного в прозаическом произведении [KoVÁCS 2012]. Поэтому интонационная метафора как языковая презентация «голоса героя», свидетельствует о том, как неповторимый поступок в свете личного высказывания оказывается потенциальным текстом.

Не менее значительны работы, в которых изучается явление «метафорической дигрессии». Речь идет о взаимодействии семантической и интонационной метафоры. В прозаическом тексте существуют отступления (парабаза, сказ) в том пункте детализации сюжета, где обнаруживается кризис повествовательной речи, например, в «лирических отступлениях» Гоголя в «Мертвых душах» (или пейзаж у Тургенева, закат у Достоевского). Нехватка нарративного текстопорождения восполняется в отступлении метафорической моделью субъекта речи, нередко свидетельствующая о «кризисе автора» рассказывания. Смысловой презентации голоса писателя служит метафорическое высказывание по поводу взаимодействия «унылой» песни и тройки. Смысловой потенциал этого отступления побуждает мысль о природе авторства в плане личной самопрезентации, манифестируя тоску по персональной идентичности в плане прозаического дискурса. 
Субъект дискурса является темой изучения также в плане «персонального повествования», охватывающего вопросы взаимодействия метафоры с перволичным рассказом и дискурсом, в том числе и на уровне жанровой многоязычности прозы.

Подытоживая сказанное, можно утверждать, что изучать метафору наиболее комплексно позволяет литературоведческий подход, выдвигающий семантический и дискурсивный аспекты для анализа и интерпретации поэтического текста. Лингвистический метод позволяет систематизировать полученные результаты. Следует обратить внимание и на то, что литературные метафоры, как результаты творческой силы языка человека, не только представляют собой нечто общее с человеческим опытом, но и отличаются друг от друга, свидетельствуя о собственной языковой картине мира. Категоризация индивидуальных метафор отдельных авторов же делает возможным их последующее сопоставление с метафорами других поэтов и писателей разных национальностей и культур. Таким образом, метафорическую картину мира в литературе раскрывает лингвистический подход в сочетании с поэтическим.

В литературоведческом разделе настоящего журнала [SLAVICA 2019] приводятся яркие примеры того, как метафора может представиться отношением как между словами, в которых мы используем одно обозначение для создания и освещения другого, так и между словами и высказыванием в целом, в то же время, как ее можно классифицировать и систематизировать по понятиям.

\section{Литература}

Арутюнова 1990: Арутюнова, Н. Д. Метафора и дискурс // Арутюнова, Н. Д. - Журинская М. А. (ред.) Теория метафоры. Москва: Прогресс 5-32.

АрутюновА 1999: Арутюнова, Н. Д. Язык и мир человека: Языковая метафора (синтаксис и лексика). Москва: Яз. рус. культ.

АРУТЮНОВА-ЖуриНСКАЯ 1990: Арутюнова, Н. Д. - Журинская, М. А. (ред.) Теория метафоры. Москва: Прогресс.

БАРАНОВ 1992: Баранов, Г. С. Научная метафора: модельно-семиотический подход. Ч. 1. Современные лингвофилософские концепции метафоры. Кемерово: Кузбассиздат.

БиКЕРТОН 1990: Бикертон, Д. Введение в лингвистическую теорию метафоры. (Пер. Н. Н. Перцовой) // Арутюнова, Н. Д. - Журинская, М. А. (ред.) Теория метафоры. Москва: Прогресс 284-306.

Бирдсли 1990: Бирдсли, М. Метафорическое сплетение. (Пер.Н. Н. Перцовой) // Арутюнова, Н. Д. - Журинская, М. А. (ред.) Теория метафоры. Москва: Прогресс 201-218.

БлэК 1990: Блэк, М. Метафора (Пер. М. А. Дмитровской) // Арутюнова, Н. Д. - Журинская М. А. (ред.) Теория метафоры. Москва: Прогресс 153-172.

ВЕжБицКАЯ 1990: Вежбицкая, А. Сравнение - градация - метафора. (Пер. Г. Е. Крейдлина) // Арутюнова, Н. Д. - Журинская, М. А. (ред.) Теория метафоры. Москва: Прогресс 133-152.

Выготский 1999: Выготский, Л. С. Мышление и речь. Москва: Лабиринт.

ГАК 1973: Гак, В. Г. Высказывание и ситуация // Проблемы структурной лингвистики.1972. Москва: Наука 349-372. 
ГУдмен 1990: Гудмен, Н. Метафора - работа по совместительству. (Пер. Р. И. Розиной) // Арутюнова, Н. Д. - Журинская, М. А. (ред.) Теория метафоры. Москва: Прогресс 194-200.

ГумьОльдт 2000: Вильгельм фон Гумбольдт. Избранные труды по языкознанию. (Пер. Ш. В. Рамишвили). Москва: Прогресс.

ДоБЖиньСКАЯ 1990а: Добжиньская, Т. Метафорическое высказывание в прямой и косвенной речи. (Пер. Г. Е. Крейдлина) // Арутюнова, Н. Д. - Журинская, М. А. (ред.) Теория метафоры. Москва: Прогресс 456-475.

ДоБжиньскАЯ 1990б: Добжиньская, Т. Метафора в сказке. (Пер. А. Л. Майорова) // Арутюнова, Н. Д. - Журинская, М. А. (ред.) Теория метафоры. Москва: Прогресс 476-492.

ДэвидсОН 1990: Дэвидсон, Д. Что означают метафоры. (Пер. М. А. Дмитровской) // Арутюнова, Н. Д. - Журинская, М. А. (ред.) Теория метафоры. Москва: Прогресс 173-193.

КАССИРЕР 1990: Кассирер, Э. Сила метафоры. (Пер. Т. В. Топоровой) // Арутюнова, Н. Д. - Журинская, М. А. (ред.) Теория метафоры. Москва: Прогресс 33-42.

КовАч 2012: Ковач, Арпад. Персонализм литературной антропологии Михаила Бахтина (От феноменологической эстетики к поэтике прозы). Russian Literature LXXII-I. 1-44.

КовАч 2015: Ковач, Арпад. Дискурс, рассказ и троп. («Покой» в творчестве Пушкина) // О.В. Федунина и Ю.Л. Троицкий (ред.) Диалог согласия: сборник научных статей к 70-летию В.И. Тюпы. Москва: Intrada 336-349. - О поэтических фигурах кореференций в русской литературе XIX века // Каталин Кроо (глав. ред.). Голоса русских филологов из Будапешта. Литературоведение и языкознание на Кафедре русского языка и литературы Университета им. Лоранда Этвеша. Будапешт. 2018. 95-117.

КОЖЕВНИКОВА 2009: Кожевникова, Н. А. Избранные работы по языку художественной литературы. Москва: Знак.

ЛАКОФФ-ДжОНСон 1990: Лакофф, Дж. - Джонсон, М. Метафоры, которыми мы живем. (Пер. Н. В. Перцова) // Арутюнова, Н. Д. - Журинская, М. А. (ред.) Теория метафоры. Москва: Прогресс 387-415.

ЛАКОФФ-ДжОНСОН 2004: Лакофф, Дж. - Джонсон, М. Метафоры, которыми мы живем. Москва: УРСС.

ЛЕВИн 1965: Левин, Ю. И. Структура русской метафоры // Труды по знаковым системам. Тарту. Т. 2. 293-299.

ЛЕВин 1990: Левин, С. Прагматическое отклонение высказывания. (Пер. Н. В. Перцова // Арутюнова, Н. Д. - Журинская, М. А. (ред.) Теория метафоры. Москва: Прогресс 342-357.

МАККОРМАК 1990: МакКормак, Э. Когнитивная теория метафоры. (Пер. А. Д. Шмелева // Арутюнова, Н. Д. - Журинская, М. А. (ред.) Теория метафоры. Москва: Прогресс 358-386.

МЕзЕНИН 1984: Мезенин, С. М. Образные средства языка. Москва: Издательство ТюмГУ.

МилЛЕР 1990: Миллер, Дж. Образы и модели, уподобления и метафоры. (Пер. В. В. Туровского) // Арутюнова, Н. Д. - Журинская, М. А. (ред.) Теория метафоры. Москва: Прогресс 236-283.

Москвин 1997: Москвин, В. П. Русская метафора. Семантическая, структурная, функциональная классификация. Волгоград: Перемена.

ОРТЕГА-И-ГАССЕТ 1990: Ортега-и-Гассет, Х. Две великие метафоры. (Пер. Н. Д. Арутюновой) // Арутюнова, Н. Д. - Журинская, М. А. (ред.) Теория метафоры. Москва: Прогресс 68-81. 
ОРтони 1990: Ортони, Э. Роль сходства в уподоблении и метафоре. (Пер.с английского В. В. Туровского) // Арутюнова, Н. Д. - Журинская, М. А. (ред.) Теория метафоры. Москва: Прогресс 219-235.

ПЕТРОВА 1989: Петрова, 3. Ю. Регулярная метафорическая многозначность в русском языке как проявление системности метафоры // Проблемы структурной лингвистики. 1985-1987. Москва: Прогресс.

ПотЕБНЯ 2003: Потебня, А. А. Теоретическая поэтика. Москва-Санкт-Петербург: Академия.

РикЁР 1990а: Рикёр, П. Метафорический процесс как познание, воображение и ощущение. (Пер. М. М. Бурас и М.А. Кронгауза) // Арутюнова, Н. Д. - Журинская, М. А. (ред.) Теория метафоры. Москва: Прогресс 416-434.

РикЁР 1990б: Рикёр, П. Живая метафора. (Пер. А. А. Зализняк) // Арутюнова, Н. Д. Журинская, М. А. (ред.) Теория метафоры. Москва: Прогресс 435-455.

РичАРДС А. 1990: Ричардс А. Философия риторики. (Пер. Р. И. Розиной) // Арутюнова Н. Д. - Журинская М. А. (ред.) Теория метафоры. Москва: Прогресс 44-67.

Рыньков 1975: Рыньков, Л. Н. Типы метафорических словосочетаний в языке литературы // Русский язык в школе. 1. 45.

СЕРЛь 1990: Серль, Дж. Метафора. (Пер. В. В. Туровского) // Арутюнова, Н. Д. - Журинская, М. А. (ред.) Теория метафоры. Москва: Прогресс 307-341.

СкЛЯРЕВСКАЯ 1993: Скляревская, Г. Н. Метафора в системе языка. РАН. Ин-т лингв. исслед. Санкт-Петербург: Наука.

ТЕЛИя 1988: Телия, В. Н. Метафоризация и ее роль в создании языковой картины мира // Б.А. Серебренников (отв. ред.) Роль человеческого фактора в языке. Язык и картина мира. Москва: Наука 173-203.

ТомАшЕВский 2001: Томашевский, Б. В. Теория литературы. Поэтика. Москва: Аспект-Пресс.

УИЛРАЙт 1990: Уилрайт, Ф. Метофора и реальность. (Пер. А. Д. Шмелева) // Арутюнова, Н. Д. - Журинская, М. А. (ред.) Теория метафоры. Москва: Прогресс 82-109. ФРЕЙДЕНБЕРГ 1936: Фрейденберг, О. М. Поэтика сюжета и жанра. Ленинград: Гослитиздат. ФРЕЙДЕНБЕРГ 1978: Фрейденберг, О. М. Миф и литература древности. Москва: Наука.

ШЕЛЕСТЮк 2001: Шелестюк, Е. В. Метафора: двухкомпонентная или трехкомпонентная структура? // Актуальные проблемы лингвистики: Уральские лингвистические чтения. Материалы... конференции. Екатеринбург: Издательство УрГПУ 125-126.

ЯкоБСОН 1990: Якобсон, Р. Два аспекта языка и два типа афатических нарушений. (Пер. Н. В. Перцова) // Арутюнова, Н. Д. - Журинская, М. А. (ред.) Теория метафоры. Москва: Прогресс 110-132.

ARISZTOTELÉSZ 1997: Arisztotelész. Poétika és más költészettani írások. (Ford.: Ritoók Zsigmond.) Budapest: PannonKlett.

BENYOVSZKY 2006: Benyovszky Krisztián. Az elbeszélt metafora // Világosság 8-9-10. 137-144.

BEZECKY 1990: Bezecky Gábor. A jelentésteremtő metafora // Helikon 4. 379-389.

BEZECKY 1992: Bezecky Gábor. Metafora és elbeszélés. // Literatura 1. 25.

BEZECKY 2002.: Bezecky Gábor. Metafora, narráció, szociolingvisztika. Budapest: Akadémiai Kiadó.

CORTAZZI-JIN 1999: Cortazzi, Martin - Jin, Lixian. Bridges to learning: Metaphors of teaching, learning and language. // Cameron Lynne (ed.) Reasearching and applying metaphor. Cambridge: Cambridge University Press 149-76.

DE MAN 1999: De Man, Paul. Az olvasás allegóriái. (Ford.: Fogarasi György.) Szeged: Ictus-JATE. GENETTE 1977: Genette, Gerard. A leszükült retorika. (Ford.: Vígh Árpád) Helikon 1. 60-71. 
GIBBS 1994: Gibbs, Raymond W. The poetics of mind: figurative thought, language, and understanding. Cambridge; New York: Cambridge University Press.

HaLliDAY 1978: Halliday, M. A. K. Language as Social Semiotics. Baltimore: University Park Press.

HORVÁTH 2003: Horváth Kornélia. A szó mint metafora. A retorika, jelelmélet és nyelvelmélet összefüggéséröl // Világosság. 11-12. 143-149.

KoszTOLÁNYI 1971: Kosztolányi Dezső: Nyelv és lélek. Budapest: Szépirodalmi Könyvkiadó. 46-47.

KovÁCs 2013: Kovács Árpád. Mi az egzisztenciális metafora? // Literatúra. 39. 2. 95-114.; - La métaphore et l'identité générique (L'actualité de Northrop Frye) // Genres et identité dans la tradition littéraire européenne. Orizons, Comparaisons, Paris, 2017. 49-62.

KOVECSES 2002: Kovecses, Zoltan. Metaphor: A practical introduction. Oxford: Oxford University Press.

KÖVECSES 2005: Kövecses Zoltán. A metafora. Budapest, Typotext.

SLAVICA 2019: Slavica 48, v pečati.

STEEN 1999: Steen, Gerard. Metaphor and discourse: Towards a linguistic checklist for metaphor analysis. // Cameron Lynne (ed.) Reasearching and applying metaphor. Cambridge: Cambridge University Press 81-104.

TODOROV 1977: Todorov, Tzvetan. Trópusok és figurák. (Ford.: Vajda András). Helikon 1. 30-40.

Ангелика МолНАР

Дебреценский университет

Дебрецен, Венгрия

angelika.molnar@arts.unideb.hu 